\title{
Role zawodowe w polskich podręcznikach do nauczania religii katolickiej w ujęciu krytyki genderowej na przykładzie podręczników wydawnictwa WAM
}

Od kiedy rodzicie dowiadują się, jakiej płci będzie płód, zaczynają postrzegać go jako chłopca lub dziewczynkę. Płeć jest bardzo ważnym czynnikiem porządkującym nasze życie. Polskie badaczki zauważają, że „określenie jestem kobietą, jestem mężczyzną daleko wykracza poza anatomiczną charakterystykę, niosąc ze sobą pewną konfigurację cech/ charakteru, wzorów zachowań"1. Anthony Giddens pisze o tym jeszcze dobitniej: „Wszystkie aspekty naszego życia, od tonacji głosu, przez gesty i sposób poruszania się do norm zachowań, związane są z płcią"2. Płeć ma wpływ na nasze definiowanie własnej tożsamości, daje o sobie znać w codziennych czynnościach oraz ujawnia się w sposobie, w jaki traktują nas inni ludzie. W społeczeństwie istnieją pewne modele kobiecości i męskości porządkujące rzeczywistość. Zmiany w obrębie owych wzorców zachodzą, jednak są bardzo powolne. Gwałtowne zmiany "mogą być destrukcyjne dla całego systemu społecznego"3 ${ }^{3}$, jednak gdy porównamy to, co naszym babciom wydaje się kobiece, a co męskie z tym, jak my to definiujemy, z pewnością dostrzeżemy wiele zmian.

Każdy człowiek, niezależnie od wieku, odgrywa w swoim życiu wiele ról społecznych, należąc do różnorodnych grup. Mariusz Zemło uważa, że role społeczne należą

${ }^{1}$ B. Kowalska, K. Zielińska, B. Koshalka, Płeć w badaniach socjologicznych wprowadzenie, [w:] B. Kowalska, Gender kobieta w kulturze i społeczeństwie, Kraków 2009, s. 7.

2 Ibidem.

3 Ibidem, s. 8. 
do „ważniejszych determinant kształtujących nasze postrzeganie świata u elementów doń przynależących" ${ }^{4}$. Czym więc one są? Role społeczne wyrażają się jako zespół zachowań, obowiązków, możliwości, które w danym miejscu, okolicznościach reprezentuje jednostka. Mają charakter normatywny, regulują „zakres i odpowiedni charakter zachowań, które te jednostki powinny urzeczywistniać w swych aktywno-

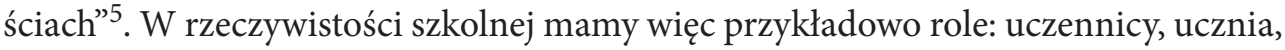
nauczycielki, nauczyciela, wychowawczyni, wychowawcy, kolegi, koleżanki z klasy itp. Natomiast w rzeczywistości rodzinnej - córki, syna, matki, ojca. Jak widać, do odgrywania tych ról istotna jest płeć jednostki. Co więcej, role społeczne wchodzą w relacje władzy, pojawia się pewna hierarchia, np. nauczyciel-uczeń, rodzic-dziecko.

Rola płciowa jest konstruktem teoretycznym, ma charakter umowny. Można modyfikować jej treści i znaczenie, co często „staje się pierwszym krokiem ku samorealizacji i odzyskaniu [utraconej] podmiotowości”' Modyfikacje te nie są rzeczą łatwą, zmuszają do wyjścia poza schematy stereotypów i autostereotypów związanych z płcią. Wymagają odwagi narażenia się na sankcje społeczne wynikające z negowania zastanego obrazu świata, którego ramy kulturowe ujęte są właśnie przez obowiązujące $\mathrm{w}$ danym społeczeństwie stereotypy płciowe. Zmiany kulturowe są procesami długotrwałymi i bardzo trudnymi.

Badania genderowe skupiają się na analizie, jak w danej kulturze definiowana jest męskość oraz kobiecość, $w$ jaki sposób przydzielane są role płciowe, jak są one realizowane, jakie cechy przypisywane są kobietom, a jakie mężczyznom. Badacze obserwują także proces socjalizacji oraz komunikacji. Analizują sposób wychowywania dziewczynek i chłopców. Przedmiotem badań jest również kobiecy i męski styl komunikacyjny. Do takiej analizy konieczna jest znajomość stereotypów związanych z płcią oraz kulturowego dekodowania płci.

W niniejszym artykule przedstawię i poddam analizie role zawodowe występujące w podręcznikach do religii katolickiej w ujęciu krytyki genderowej zestawionej z feminizmem katolickim i personalistyczną koncepcją wychowania Kościoła katolickiego. Przyjrzę się, w jaki sposób płeć determinuje wybór roli zawodowej oraz w jakich zawodach prezentowane są kobiety, a w jakich mężczyźni. Sprawdzę, czy podręczniki do religii katolickiej utrwalają patriarchalny obraz świata czy też walczą ze stereotypami płci. Mariola Chomczyńska-Rubacha zauważa, że stereotypy związane z płcią „stanowią względnie stałe struktury powstające jako rezultat transmisji wzorców kul-

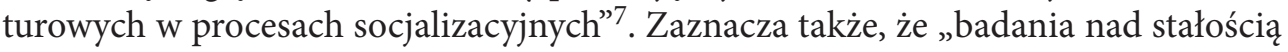
i zmiennością stereotypów płci nie ujawniają znaczących różnic w posługiwaniu się

4 M. Zemło, Role społeczne a postrzeganie szkoły, Białystok 2009, s. 43.

5 Ibidem, s. 7.

6 Ibidem, s. 8.

7 M. Chomczyńska-Rubacha, Wpływ działań edukacyjnych na spostrzeganie stereotypów płciowych, [w:] idem, Role płciowe kultura i edukacja, Łódź 2006, s. 111. 
nimi w wymiarze międzypokoleniowym" ${ }^{8}$. Praktyka kulturowa legitymizuje natomiast zastane stereotypy płciowe. Przeanalizuję, jaką rolę w tym procesie odgrywa nauczanie religii $\mathrm{w}$ szkołach państwowych, opierając się na analizie podręczników do religii.

\section{Przedstawienie materiału badawczego i metody badawczej}

Aby zbadać problem ról płciowych w polskich podręcznikach do nauczania religii katolickiej, postanowiłam sięgnąć do podręczników, z których uczą się brzescy uczniowie. Kierowałam się kryterium dostępności materiałów oraz aktualności. Wykazy podręczników uzyskałam od nauczycieli religii w brzeskich szkołach (ILO), uczniów (PG nr 4) oraz w sekretariacie szkoły, w którym do publicznej wiadomości podawany jest wykaz wszystkich podręczników używanych w szkole (PSP nr 3). Ponadto wybór takich podręczników sprawił, że mogłam zbadać, w jaki sposób dzieci dowiadują się o rolach płciowych od początku swojej edukacji do końca. Wszystkie podręczniki pochodzą od jednego wydawcy, dzięki czemu mogłam zobaczyć, czy wizerunki płci zmieniają się w zależności od wieku odbiorców.

W Publicznej Szkole Podstawowej nr 3 im. Jana Kochanowskiego w Brzegu uczniowie od klasy pierwszej do szóstej korzystają z podręczników wydawnictwa WAM oraz z zeszytów ćwiczeń zalecanych przez autorów jako uzupełnienie. Są to kolejno w klasach I-III seria „W drodze do Wieczernika”: W domu i rodzinie Jezusa, Bliscy sercu Jezusa, Jesteśmy w rodzinie Pana Jezusa. W klasach IV-VI dzieci używają podręczników: Zaproszeni przez Boga, Obdarowani przez Boga, Przemienieni przez Boga.

W Publicznym Gimnazjum nr 4 z Oddziałami Integracyjnymi w Brzegu obowiązuje seria podręczników „Odsłonić twarz Chrystusa”, również wydawnictwa WAM. Dla klasy pierwszej jest to książka Szukam Was, dla drugiej — Jestem z Wami, a dla trzeciej - Chodźmy razem.

W Liceum Ogólnokształcącym nr 1 im. Bolesława Chrobrego w Brzegu nauczyciele religii także korzystają z podręczników wydawnictwa WAM. Uczniowie nie są jednak obligowani do zakupu własnych podręczników. Książki dostępne są w sali katechetycznej. Gdy są potrzebne na lekcji, katecheta rozdaje je uczniom. Książki do liceum stanowią serię „Drogi świadków Jezusa”. W klasie pierwszej korzysta się $\mathrm{z}$ książki Jestem świadkiem Chrystusa w Kościele, w drugiej Jestem świadkiem Chrystusa $w$ świecie, natomiast $\mathrm{w}$ trzeciej nie korzysta się z nowego podręcznika, tylko kontynuuje część drugą. W sumie analizie poddam jedenaście książek. Pokrótce przedstawię wszystkie badane przeze mnie podręczniki.

8 Ibidem, s. 112. 


\section{Funkcje podręczników do religii}

Paweł Mąkosa wyróżnia sześć funkcji podręcznika do religii: informacyjną, motywacyjną, kontrolną, samokształceniową, badawczą oraz praktyczną. Badacz zaznacza, że w przypadku podręczników szkolnych funkcja informacyjna jest funkcją nadrzędną w stosunku do pozostałych. Podręcznik jest zbiorem informacji, które uczeń przyswaja w toku kształcenia, staje się źródłem wiedzy.

Funkcja informacyjna, odniesiona do podręcznika do religii, „wiąże się ściśle $\mathrm{z}$ rozwijaniem poznania wiary, będącym jednym z podstawowych zadań katechezy”; wiedza, jej pogłębianie i zdobywanie, jest niezbędna w procesie „formacji człowieka" ". Funkcji informacyjnej mogą służyć teksty zamieszczone w podręczniku do pamięciowego przyswojenia, np. modlitwy. Piotr Tomasik mówi wręcz o pewnej gotowej wiedzy podawanej uczniom ${ }^{10}$. Przestrzega jednak przed przeładowaniem podręcznika informacjami, gdyż za dużo informacji powoduje zniechęcenie ucznia, odciąga go od pracy z podręcznikiem, czyli osiąga całkiem odwrotny od zamierzonego skutek. Co ciekawe i warte zacytowania, P. Tomasik wyraża troskę o to, aby „podręczniki katechetyczne zawierały informację prezentującą "zdrową" naukę katolicką"11. Niestety nie tłumaczy, w czym objawia się stan zdrowia lub choroby nauki katolickiej. Ponadto Paweł Mąkosa pisze o tym, że treści, które zamieszczone są w podręcznikach, muszą stanowić potwierdzenie postawy Kościoła, a nie ma w nich miejsca na tzw. spekulacje teologiczne, co nie znaczy, że należy pomijać tematy trudne czy dyskusyjne.

Funkcja motywacyjna wiąże się ze zbudowaniem relacji emocjonalnej między uczniem a przedmiotem nauczania. Podręcznik służy tu kreowaniu pozytywnej identyfikacji ucznia z przedmiotem, dlatego że pozytywne nastawienie do przedmiotu „znacznie zwiększa efektywność procesu dydaktycznego" ${ }^{12}$. Funkcja motywacyjna w podręcznikach do religii zdaje się mieć ogromne znaczenie w zlaicyzowanym świecie. Mąkosa zauważa, że młodzież przestaje interesować się kwestiami religijnymi, uważając je za nudne, przebrzmiałe, dlatego według badacza trzeba na nowo zainteresować i przyciągnąć uczniów do religii. Sposobem na ich przyciągnięcie ma być mówienie w podręcznikach o kwestiach, które żywo dotyczą uczniów. Ma się to odbywać „poprzez podejmowanie problemów egzystencjalnych młodzieży oraz stosowanie zrozumiałego i bliskiego odbiorcom języka, a więc odległego od teologicznego języka dokumentów Kościoła"13. Zgodnie z tym założeniem uczniowie sami, z własnej woli, chętnie będą czytać o tym, co ich dotyczy, nurtuje, interesuje. Zauważa to także To-

9 P. Mąkosa, Poszukiwanie optymalnego podręcznika do katechezy, Lublin 2009, s. 171.

10 P. Tomasik, Jaka jest przyszłość podręczników?, [w:] M. Zając, Katecheza w szkole wspótczesnej, Lublin 2010, s. 43, 171.

11 Ibidem, s. 43.

12 P. Mąkosa, op. cit., s. 172.

13 Ibidem, s. 173. 
masik, który mówi, że podręcznik do katechezy pełni funkcję motywacyjną na dwa sposoby. Po pierwsze, „winien uwzględnić zwrot antropologiczny, jaki się dokonał we współczesnej katechezie" ${ }^{14}$, czyli właśnie to ukierunkowanie na ucznia, na jego świat i problemy. Natomiast drugim wymiarem realizacji funkcji motywacyjnej jest mówienie przystępnym, zrozumiałym językiem, unikając oczywiście trywializacji treści.

Funkcja badawcza z kolei zakłada, że uczeń ma być nie tylko biernym adresatem treści dydaktycznych, lecz także aktywnym uczestnikiem procesu kształcenia. Podręcznik ma za zadanie budzić ciekawość młodzieży, chęć odkrywania, pobudzać do refleksji i zadawania pytań. Jednocześnie Piotr Tomasik mówi też, że należy odróżnić nauczanie teologiczne od katechetycznego. Pisze on:

Badania teologiczne są naukową refleksją nad danymi objawienia, podczas gdy katecheza jest głoszeniem, zwiastowaniem Dobrej Nowiny i ma budzić pewność wiary. Oznacza to, że katecheza i lekcja religii nie są wprowadzeniem do badań teologicznych ${ }^{15}$.

Nie oznacza to jednak, że funkcja badawcza skazana jest na niepowodzenie. Wręcz przeciwnie, wymieniana jest przez wszystkich badaczy katolickich jako jedna z cech podręcznika do religii. Funkcja badawcza ma także pomóc zrozumieć uczniom dokumenty i pisma Kościoła, a ponadto jest ona bardzo ważna „podczas poszukiwania odpowiedzi na egzystencjalne pytania i argumentów skłaniających do przyjęcia prawdy, że ostateczną odpowiedź na nie można znaleźć w Chrystusie" ${ }^{16}$. Jan Szpet dodaje, opisując funkcję badawczą, iż katechizowanie młodzieży zawiera w sobie „działalność apologetyczną, czyli poszukiwanie argumentów skłaniających do uwierzenia" ${ }^{17}$, wynika z tego, że aktywność badawcza uczniów ma objawiać się w ich samodzielnym zaangażowaniu w poszukiwanie tychże argumentów.

Funkcja praktyczna, którą Jan Szpet nazywa funkcją operacyjną, łączy wiedzę teoretyczną z praktyką. Uczeń ma się dowiedzieć, w jaki sposób wykorzystać zdobytą wiedzę w życiu oraz jakie konsekwencje wynikają z powodu poznania prezentowanych $\mathrm{w}$ podręczniku prawd. W przypadku podręcznika do religii powinno to skutkować obraniem właściwej postawy moralnej oraz doprowadzić do czynnego praktykowania wiary, przy czym „praktyka życia chrześcijańskiego winna wdrażać do zachowań i postaw w określonych sytuacjach życia, zarówno prywatnych, jak i publicznych"18. Dobrze wykształcony uczeń po lekcjach religii powinien dawać przykład zachowania katolickiego, nie tylko na lekcjach religii, lecz także poza szkołą, uosabiać świadectwo wiary swoim życiem i postawą.

Z kolei funkcja samokształceniowa ma dawać uczniowi możliwość samodzielnej pracy z podręcznikiem oraz zachęcać do dalszych poszukiwań, pogłębiania wie-

14 P. Tomasik, op. cit., s. 43.

15 Ibidem, s. 44.

16 P. Mąkosa, op. cit., s. 175.

17 J. Szpet, Jak powstaja podręczniki, [w:] Katecheza wobec zadań nowej szkoły, Poznań 1999, s. 21.

18 P. Tomasik, op. cit., s. 45. 
dzy, znajdywania dodatkowych tekstów, a nie tylko ograniczania się do korzystania z podręcznika jako jedynego źródła wiedzy. Dlatego też nauczanie nie może być tylko realizacją treści zawartych w podręczniku, podręcznik powinien pisany być „trochę na wyrost"19, aby pozostawić uchylone furtki do własnego rozwoju. Nauka nie powinna więc ograniczać się do budynku szkoły i jednej książki, a raczej stawiać przed uczniem wyzwania, z którymi będzie mógł się zmierzyć, samodzielnie korzystając z innych tekstów poznawczych.

Ostatnią z opisanych przez Mąkosę funkcji podręcznika do religii jest funkcja kontrolna. Wyróżnia się dwa rodzaje kontroli w jej obrębie: nauczycielską oraz autokontrolę uczniowską. Dobrym rozwiązaniem dla realizacji tej funkcji jest zamieszczanie podsumowań, pytań kontrolnych, sprawdzianów, jednakże

oprócz sprawdzania wiedzy religijnej podręcznik do nauki religii powinien także zawierać pytania i podejmować problemy, które odnoszą się do głębi życia religijnego i moralnego wychowanków. Chodzi tu przede wszystkim o to, aby skłaniać ucznia do refleksji dotyczącej jego wiary, uczestnictwa w sakramentach i życiu wspólnotowym ${ }^{20}$.

Refleksja ta będzie głównie udziałem samokontroli ucznia.

Warto jeszcze raz podkreślić, że instytucją opiniującą podręczniki do katechezy jest Komisja Wychowania Katolickiego oraz działające przy niej Biuro Programowania Katechezy. Eksperci z tych instytucji opiniują i dopuszczają podręczniki do użytku oraz rejestrują je w Ministerstwie Edukacji Narodowej po własnej ekspertyzie. Podręczniki zatwierdza Episkopat Polski, a Ministerstwu Edukacji są one przedkładane do wiadomości. W roku 2003, na podstawie obserwacji Biura, powstało Vademecum dla autorów i recenzentów katechetycznych. Zawiera ono „regulacje prawne odnośnie do zatwierdzania podręczników dla całej Polski oraz dla diecezji”21 oraz wytyczne w sprawie recenzowania podręczników do religii. W odróżnieniu od innych badaczy, Kulpaczyński nie przecenia roli podręcznika szkolnego - owszem, mówi, że jest on ważny, ale z drugiej strony twierdzi, że podręcznik jest jedynie pomocą dydaktyczną i tak należy go traktować. Pisze:

Były czasy, że ich [podręczników - przyp. A.W.] brakowało i wtedy większą rolę pełniły zeszyty prowadzone przez uczniów i bardziej samodzielnie przygotowywane lekcje przez katechetów. [...] Najpiękniej jest wtedy, gdy katecheta staje się „żywym podręcznikiem”, bo wtedy jest duża szansa na wspólnotowy rozwój wiary nauczyciela religii i uczniów oraz na pogłębianie przyjaźni z Jezusem Chrystusem² ${ }^{22}$.

Ukazuje się tu kolejna funkcja katechezy, jaką jest ustanowienie przyjaźni między uczniami a Jezusem. Aby do rozwoju tej przyjaźni doszło, potrzebny jest jednak pośrednik w postaci katechety, który będzie dla swoich uczniów niczym otwarta księga, z której będą czerpać. Podobnego zdania jest Tadeusz Panuś, który tak jak Kulpa-

19 Ibidem.

20 P. Mąkosa, Podstawowe funkcje podręcznika do nauczania religii, [w:] M. Zając, op. cit., s. 178.

21 S. Kulpaczyński, Ocena podręczników, [w:] Poszukiwania optymalnego podręcznika..., s. 77.

22 Ibidem, s. 86. 
czyński uważa, że podręcznik szkolny jest jedynie narzędziem, a nie celem samym w sobie. Podkreśla też rolę katechety w pracy z podręcznikiem, uważając, że „decydująca o powodzeniu podręcznika jest osobowość katechety, który potrafi umiejętnie korzystać z podręcznika, zachwycać zawartymi tam treściami”23. Podobnego zdania jest także Marian Zając, który zauważa, że stosowanie na lekcji tylko jednego środka dydaktycznego, np. podręcznika, nie będzie zbyt efektywne. Także uwypukla ważność umiejętności nauczycielskich w katechezie.

Według Mariana Zająca podręcznik odgrywa przede wszystkim rolę uzupełniającą do żywego nauczania i jednocześnie przestrzega on przed uleganiem nadmiernej „fetyszyzacji podręcznika”24, czyli sytuacji, w której przeładowany funkcją informacyjną podręcznik staje się dla ucznia jedynym źródłem wiedzy. W takim przypad$\mathrm{ku}$ „przedmiotem poznania przestaje być świat społeczny, świat kultury ludzkiej, świat religii, a staje się nim podręcznik. Takie niebezpieczeństwo powoduje sytuację, w której następuje oderwanie szkoły od życia ucznia"25.

Materiał prezentowany w podręczniku powinien odpowiadać układowi programowi nauczania, przy czym kryterium doboru treści musi uwzględniać „kryterium podwójnej wierności: Bogu i człowiekowi”"26. To oznacza, że podręcznik musi być wierny doktrynie, lecz także ma docierać do żywego odbiorcy, dbać o bycie zrozumiałym, bliskim człowiekowi. Ważne jest tu podejście dyskursywne. Uczeń nie jest wyłącznie biernym czytelnikiem, ma być aktywnym odbiorcą podręcznika, więc musi być on dostosowany do możliwości odbiorcy, poziomu zaawansowania, a także powinien zachęcać do pracy z nim. Kostorz zaleca, aby w nauczaniu początkowym treści rozłożyć na dwie strony; jedna obrazować powinna „prawdę Bożą”, druga pokazywać jej odniesienie do życia codziennego. Cytowany autor uważa, że w klasach starszych podręczniki powinny zawierać w swych treściach korelację międzyprzedmiotową oraz wiedzę interdyscyplinarną.

Wiedza, która przedstawiana jest w podręczniku, powinna być dostosowana do zakresów tematycznych zawartych w programie nauczania.

Mówi się o reprezentatywnej wiedzy podręcznika, nie opisuje się społeczeństwa wprost, ale na użytek tego opisu tworzy się wyidealizowane, a zarazem typowe przedstawienia: ról społecznych, relacji, sytuacji, wartości i norm. Wyznaczają one przestrzeń wspólnych doświadczeń kolejnych pokoleńn ${ }^{27}$.

23 T. Panuś, Podręczniki do nauki religii sens czy bezsens, [w:] J. Kostorz, Podręczniki do nauki religii sens czy bezsens, Opole 2009, s. 94.

24 M. Zając, Funkcje podręczników, s. 16.

25 Ibidem, s. 18.

26 Ibidem, s. 25.

27 Ibidem, s. 19. 


\section{Gender w procesie edukacji}

Szkoła nie tylko uczy, przekazuje wiedzę i informacje, lecz także bierze aktywny udział w dalszej socjalizacji człowieka. Siedmiolatek czy też sześciolatek (w myśl nowej reformy), przekraczając po raz pierwszy mury szkoły, ma już w głowie pewien obraz świata, opinie, zainteresowania. Wie, jak powinien się zachowywać, co jest dobre, a za co spotka go kara. W toku socjalizacji dowiaduje się, co to oznacza być dziewczynką lub chłopcem i jakie niesie to $\mathrm{z}$ sobą konsekwencje.

Proces socjalizacji związanej z płcią nie zatrzymuje się wraz z wejściem do szkoły. Jest on kontynuowany zarówno przez nauczycieli, jak i rówieśników czy też ogólnie pojmowaną szkołę jako system, w którym funkcjonuje uczeń. Socjalizacja związana z płcią skorelowana jest z kontekstem społeczno-kulturowym, w jakim działa szkoła i w takiej sytuacji. Mariola Chomczyńska-Rubacha twierdzi, że

[j]eśli spojrzeć na przedmiot badań pedagogicznych z perspektywy gender, to na czoło wysuwa się kwestia przekazów edukacyjnych dotyczących płci, definiujących pożądane z jakiegoś punktu widzenia obrazu, kobiecości i męskości oraz wynikające z nich reguły dostępu przedstawicieli obojga płci do dóbr społeczno-kulturowych ${ }^{28}$.

Badaczka początków zainteresowania gender education upatruje w 1972 roku w USA oraz w 1975 roku w Wielkiej Brytanii. Refleksja ta wpisuje się w nurt pedagogiki krytycznej.

W swoim artykule postawiłam sobie za zadanie zbadanie, jaki pożądany obraz kobiecości i męskości aprobują podręczniki do nauki religii katolickiej, które używane są w procesie edukacyjnym w polskich szkołach państwowych. Na potrzeby niniejszego tekstu problem zawęziłam do ról zawodowych.

\section{Feminizm chrześcijański. Kobieta i mężczyzna w Kościele katolickim}

W najnowszym dyskursie katolickim dużo refleksji nad kwestią miejsca kobiet i mężczyzn poświęcił Jan Paweł II. Pisał on o „prawdziwym feminizmie” lub „nowym feminizmie", który jest postawą jak najbardziej pozytywną. Jan Paweł II, w przeciwieństwie do swoich poprzedników, nie krytykuje zawodowej aktywności kobiet. Pisze, że aktywność ta jest usprawiedliwiona „[n]ie ulega wątpliwości, że równa godność i odpowiedzialność mężczyzny i kobiety usprawiedliwia w pełni dostęp kobiet do zadań publicznych"29. Jednocześnie papież nawoływał, aby odrzucić pogląd, jakoby macierzyństwo zniewalało, nie pozwalało się kobiecie realizować i aby dowartościować macierzyństwo obok innych aktywności. W liście apostolskim o godności

28 M. Chomczyńska-Rubacha, Wpływ działań edukacyjnych..., s. 6.

29 Adhoracja familiaris consortio o zadaniach rodziny chrześcijańskiej w świecie współczesnym, 1981. 
i powołaniu kobiety z 1999 roku Jan Paweł II „podkreśla, że istnieją dwa wymiary powołania kobiet: macierzyństwo i dziewictwo" 30 . Jednocześnie pisze o tym, że rodzicielstwo obejmuje zarówno matkę, jak i ojca, ale to jednak w macierzyństwie niejako naturalnie urzeczywistnia się mocniej. W pismach Jana Pawła II o nowym feminizmie kobieta bardzo często występuje jako matka.

Podczas spotkania z młodzieżą w Brazylii w 1980 roku Jan Paweł II mówił o prawdziwym feminizmie jako o „autentycznej realizacji kobiety jako osoby ludzkiej, stanowiącej integralną część rodziny i społeczeństwa, realizującej się w sposób dla niej charakterystyczny" ${ }^{31}$. Widoczne jest tu, że według nowego feminizmu kobieta jest istotą ludzką podobnie jak mężczyzna, w związku z tym ma taką samą godność, jednak stworzona jest do czego innego i jest to naturalne, zgodne z wolą Bożą jej człowieczeństwo najpełniej może rozwinąć się dopiero w macierzyństwie.

Rozróżnienie na płeć biologiczną i gender jest przez Kościół katolicki odrzucane: „W nauczaniu społecznym kościoła mamy do czynienia z naciskiem na płeć jako coś naturalnego. Płeć jest naturalna, ponieważ została dana przez Boga, a nie stworzona przez ludzi, czy kulturę"32. Teoria gender określana jest jako „ideologia gender” i ma wymiar jednoznacznie negatywny. Podejście Kościoła do płci można określić jako esencjonalistyczne ujmujące: „różnicę płci jako rzeczywistość głęboko wpisaną w kobietę i mężczyznę" ${ }^{33}$. Dodatkowo rozróżnienie na kobietę i mężczyznę wyraża komplementarność obu płci względem siebie: „Kobieta jest dopełnieniem mężczyzny, tak jak mężczyzna jest dopełnieniem kobiety: kobieta i mężczyzna są komplementarni"34. Nietrudno domyślić się, że komplementarność ta najlepiej spełnia się w małżeństwie pojmowanym jako związek kobiety i mężczyzny.

Kobieta i mężczyzna są sobie równi w godności ludzkiej, ale jednocześnie są różni, np. w zadaniach, do których powołał ich Bóg:

Osobowe zasoby kobiecości na pewno nie są mniejsze od zasobów męskości - są tylko inne. Kobieta więc - podobnie zresztą jak mężczyzna - musi pojmować swe osobowe „spełnienie”, swoją godność i powołanie w oparciu o te zasoby, według tego bogactwa kobiecości, jakie otrzymała w dniu stworzenia i które dziedziczy jako sobie właściwy obraz podobieństwa Bożego ${ }^{35}$.

Oznacza to, że różnice między kobietami i mężczyznami są cechami wrodzonymi. Zachowania i role płciowe są specjalnie zaprogramowane przez Boga, aby człowiek mógł w pełni rozwinąć swoje człowieczeństwo. Stanowisko feminizmu katolickiego znane jest teoretykom feministycznym. Można nawet odnieść wrażenie, że lepiej

30 E. Górnikowska-Zwolak, K. Rajca, Poglądy przedstawicieli Kościoła, [w:] M. Chomczyńska-Rubacha, Role ptciowe..., s. 14.

31 Ibidem, s. 22.

32 A. Szwed, Ta druga. Obraz kobiety w nauczaniu Kościoła Rzymskokatolickiego i świadomości księ$\dot{z} y$, Kraków 2015, s. 76.

${ }^{33}$ Ibidem.

34 Jan Paweł II, cyt. za: A. Szwed, op. cit., s. 77.

35 Kongregacja Nauki i Wiary 2004, cyt. za: A. Szwed, op. cit., s. 77. 
niż osobom bezpośrednio związanym z Kościołem (księża, zakonnice). Stanowisko to jest jednak krytykowane jako pewna hipokryzja. Feminizm katolicki jawi się tu jako pogląd sankcjonujący stereotypy płciowe, legitymizujące je w imię ról nadanych przez Boga. Jest to patriarchat dobrze znany, jednak ubrany w nowe słowa, podkreślający równość obu płci w godności.

\section{Role zawodowe w podręcznikach do religii — analiza materiału badawczego}

Role płciowe wynikające z pełnionego zawodu podzieliłam na te, które wykonują dorośli i dzieci. Wśród zawodowych ról dorosłych najczęściej pojawiają się: nauczycielka, nauczyciel, lekarka, lekarz, zakonnica i kapłan. Natomiast wśród dziecięcych dominują: uczeń, uczennica oraz ministrant.

\section{Nauczycielki i nauczyciele}

W podręcznikach do religii kobiety często wcielają się w role nauczycielek. Pojawiają się nauczycielki zarówno przedmiotów świeckich, jak i religii. Nauczycielki są bohaterkami opowiadań, ilustracji oraz zdjęć zamieszczonych w podręcznikach. Ważne jest, to, że „podręczniki szkole i nauczyciele mówią nam o świecie, który stworzył Bóg" ${ }^{36}$. W większości klas na ilustracjach na ścianie wisi krzyż oraz godło Polski, czasami pojawia się oprawiony w ramę portret papieża. Nauczycielki ubrane są skromnie, wręcz nobliwie, w długie spódnice, sukienki. Nie występują w spodniach.

Wyglądają jak szare myszki, z włosami zebranymi w kok lub kucyk. Nauczycielki zadają zadania domowe, wiersze na pamięć, przyniesienie do szkoły dodatkowych materiałów, np. kasztanów ${ }^{37}$. Dobre nauczycielki pomagają uczniom, jeżdżą też z dziećmi na wycieczki klasowe ${ }^{38}$. Pocieszają płaczące uczennice; płaczących uczniów do pocieszania nie ma. Nauczycielka-katechetka prowadzi lekcje religii. Zawsze pokazywana jest w sposób pozytywny; modli się z uczniami, czyta im Pismo Święte ${ }^{39}$. Na lekcjach panuje dyscyplina, dzieci biorą czynny udział w lekcji, w skupieniu słuchają słów nauczycielki. Wśród katechetek nie ma przykładów nauczycielek surowych.

W analizowanych podręcznikach zauważyłam, że występują w nich też nauczycielki surowe. Przykładem jest nauczycielka z opowiadania z klasy pierwszej gim-

\footnotetext{
36 Podręcznik do klasy pierwszej, s. 39.

37 Ibidem s. 86

38 Podręcznik do klasy trzeciej, s. 15.

39 Podręcznik do klasy pierwszej, s. 114.
} 
nazjum ${ }^{40}$. Dzieci przezywają ją Helga, ale przyznają, że choć jest surowa, to jest dobrą nauczycielką. Na ilustracjach często powtarza się motyw nauczycielki, która daje uczniowi jedynkę ${ }^{41}$. Co ciekawe, nie ma ilustracji, w których uczennica jest w takiej sytuacji. Uczennice nie dostają jedynek. Surową nauczycielką jest także Ekierka, matematyczka, postrach całej szkoły. Uczniowie czują przed nią respekt. Cały obraz okazuje się jednak pozorny, nauczycielka nadużywa swojej władzy w stosunku do ucznia, który się spóźnił na lekcję. Mimo przeprosin chłopca, drąży ona temat jego spóźnienia. Dyscyplina znika. Chłopiec staje się obiektem kpin kolegów, a nauczycielka nie reaguje.

Występują także nauczycielki-siłaczki, poświęcające się swojej pracy. Nauczanie jest dla nich misją społeczną. Takie nauczycielki dobro uczniów przedkładają nad własne. Są przemęczone „[o]czy piekły Helenę ze zmęczenia. Wczoraj znowu poszła spać grubo po północy. Chciała sprawdzić prace klasowe, żeby dzisiaj oddać je uczniom"42.

Po raz pierwszy rola nauczyciela występuje w podręczniku do klasy czwartej szkoły podstawowej. Co ciekawe, w tym podręczniku nie występuje rola nauczycielki. Nauczyciel pełni tu funkcję wychowawcy klasy ${ }^{43}$. Jest to przypadek, kiedy funkcję typowo opiekuńczo-wychowawczą, stereotypowo przypisaną kobiecie, sprawuje mężczyzna. Może to jednak wynikać z tego, że dawniej w szkołach uczyli tylko nauczyciele. To z kolei ma podbudowę w archetypie Chrystusa-Nauczyciela. O czym mówi Jan Paweł II, nazywając ideał wychowania integralnego „wyższą transcendentną pedagogią Chrystusa-Nauczyciela" ${ }^{44}$. Nauczyciel-katecheta występuje w podręczniku do pierwszej klasy gimnazjum. Uczeń mówi o nim: „Nasz katecheta opowiadał naprawdę ciekawe rzeczy"45. Oczekiwania wobec nauczycieli są o wiele wyższe. Papież uważa, że powinni oni pracować z poświęceniem, bo ,jest to wielkie powołanie i Pan sam wynagrodzi wszystkich tych, którzy się temu oddają, jako wychowawcy w służbie Słowa Bożego"46.

\section{Zawody związane ze służbą zdrowia}

W toku dalszej analizy zauważyłam, że lekarzami w podręcznikach do religii częściej są mężczyźni, ale zdarzają się także kobiety wykonujące ten zawód. Przykładowo mama Małgosi. Rodzice dziewczynki są lekarzami ${ }^{47}$. Podczas rodzinnego spaceru

\footnotetext{
40 Podręcznik do klasy pierwszej gimnazjum, s. 86.

41 Podręcznik do klasy drugiej gimnazjum, s. 10.

42 Podręcznik do klasy trzeciej gimnazjum, s. 18.

43 Podręcznik do klasy czwartej, s. 116.

44 P. Kazimierczak, Personalistyczna koncepcja wychowania w nauczaniu Jana Pawła II, Kraków 2003, s. 146.

45 Podręcznik do klasy pierwszej gimnazjum, s. 5.

46 Paweł Kazimierczak, op. cit., s. 94.

47 Podręcznik do klasy trzeciej gimnazjum, s. 34.
} 
lekarka postanawia pomóc leżącemu na chodniku człowiekowi, podczas gdy jej mąż nie podejmuje żadnych działań. Lekarka nie zważa na stan leżącego człowieka. Kieruje się wartościami wyższymi. Jej praca jest dla niej misją, służbą, która nie trwa od danej godziny do danej godziny, zawsze jest gotowa nieść pomoc, sama mówi: „Ja nigdy nie jestem po pracy" ${ }^{48}$. Wobec kobiet postawione są wyższe standardy i wymagania. Oczekiwanymi cechami są poświęcenie i bezinteresowność. Lekarka wykazała się odwagą i miała w sobie „ducha ofiary" 49 w pracy dla innych.

Lekarz przedstawiony jest pozytywnie, jako zawód zaufania społecznego. Jest to osoba skora do poświęceń, niosąca pomoc bliźniemu. Lekarz pomaga każdemu bez względu na wagę dolegliwości, od pomocy przejedzonemu chłopcu po wyjazd do poważnego wypadku. Lekarz-ojciec często jest nieobecny w domu. W każdej chwili mogą go wezwać do szpitala. Lekarz-ojciec to również powód do dumy. W jednym z podręczników chłopiec chwali się, że jego tata ratuje ludziom życie w skomplikowanych operacjach. Mężczyźni są przedstawieni jako wykwalifikowani specjaliści.

W podręcznikach ukazane są zawody zaufania społecznego, misyjne, nastawione na pracę z ludźmi. Od takich ludzi wymaga się więcej. Co ważne, więcej wymaga się od kobiet, mają one pracować bardziej ofiarnie i z większym poświęceniem (nauczycielka, lekarka, zakonnica). Natomiast od mężczyzn wymaga się większego profesjonalizmu i specjalizacji (nauczyciel, ksiądz, lekarz). Wynika to z tradycyjnego podziału ról płciowych.

\section{Zawody związane ze służbą Bogu}

W podręcznikach kobiety i mężczyźni występują też w rolach duchownych - jako zakonnice, zakonnicy oraz księża. Kwestia ich celibatu była już poruszana przy opisie ról małżonków i właściwego korzystania z płodności. Wybór takiej drogi życiowej jest „aktem miłości, chęcią upodobania się do Jezusa [...] życie zakonne w swoich różnych formach zmierza do tego, by było znakiem miłości Bożej wyrażonej językiem naszych czasów” ${ }^{50}$. Ponadto: „życie zakonne wypływa z tajemnicy Kościoła. Jest ono darem, który Kościół otrzymuje od swojego Pana"51. Zakonnice często portretowane są $\mathrm{w}$ towarzystwie dzieci. Występują np. zakonnice-nauczycielki, które prowadzą w szkołach lekcje katechezy.

Zakonnice-misjonarki wyjeżdżają na misje Kościoła katolickiego i sprawują tam różną działalność. Mogą prowadzić szkołę albo szpital, w których: „opiekują się ludź-

\footnotetext{
48 Podręcznik do klasy trzeciej gimnazjum, s. 42.

49 Paweł Kazimierczak, op. cit., s. 146.

50 Podręcznik do klasy pierwszej liceum, s. 107.

51 Ibidem.
} 
mi, głosząc słowo Boże”52 oraz: „pokazują im [potrzebującym], jak bardzo Jezus ich kocha" ${ }^{33}$. Na misjach zakonnice opiekują się chorymi jak pielęgniarki ${ }^{54}$.

Zakonnice oczywiście angażują się też w życie Kościoła. Najczęściej ich działalność związana jest $\mathrm{z}$ dziećmi. Prowadzą kościelny chór dziecięcy, przygrywając wesoło na gitarach. Pomagają potrzebującym, np. przez gotowanie i rozdawanie potrzebującym gorącej zupy. Ich posługa jest definiowana przez Kościół jako kobiety konsekrowanej - „taka czułość to prawdziwe macierzyństwo gotowe do rozdania w każdej chwili, każdemu człowiekowi. To macierzyństwo na poziomie prawie Boskim, najważniejsze w życiu zakonnym" ${ }^{\prime 5}$. Przez rolę zakonnicy kobieta, po pierwsze, dochowuje ślubów czystości, stając się wzorem wstrzemięźliwości. Po drugie, realizuje swoje zadania opiekuńcze poprzez macierzyństwo duchowe, dzięki któremu „przekazuje żywe słowa Boga”.

Podczas analizy zauważyłam, że ksiądz jest rolą, która występuje we wszystkich podręcznikach. Związana jest ona $\mathrm{z}$ wyjątkową misją. Księża przedstawieni są w różnych sytuacjach. Zawsze występują w szatach liturgicznych lub chociaż z koloratką nawet jak ksiądz-wujek odwiedza chorego chłopca, jest ubrany w strój „służbowy”.

Księża pełnią w podręcznikach role wynikające $\mathrm{z}$ ich zawodu. Prowadzą mszę. Spowiadają wiernych. Udzielają komunii. Namaszczają chorych. Udzielają ślubów i organizują pogrzeby. Robią to, dlatego że „wszyscy księża zakochali się w panu Jezusie" 56 . Autorzy podręcznika do klasy drugiej porównują księży do słoneczników: „Tak jak słonecznik wskazuje, z której strony świeci słońce, tak ksiądz chce pokazać nam Pana Jezusa" ${ }^{57}$. Wielokrotnie zostaje podkreślona wyjątkowa bliskość księży z Panem Jezusem.

W podręcznikach występują także księża-katecheci. Prowadzą oni lekcje religii w szkołach. Sytuacja taka występuje w wielu podręcznikach. Jeżdżą też z dziećmi na kolonie organizowane przez Caritas jako wychowawcy. Najczęściej ksiądz jest portretowany w sposób podkreślający dystans, jaki dzieli go od wiernych. Może to wynikać z tego, iż: „ludzie oczekują od kapłanów tylko jednego, aby byli specjalistami od spotkania człowieka z Bogiem. Oczekuje się od niego, by był ekspertem w dziedzinie życia duchowego" ${ }^{58}$. Kapłaństwo określane jest również jako „święta funkcja i urząd" "59. Zauważyłam, że autorzy podręczników są niekonsekwentni. W większości przypadków podkreślany jest specjalny status księdza. Pokazywany jest na podwyższeniu, często z żabiej perspektywy, w bogato zdobionych szatach liturgicznych, przy

\footnotetext{
52 Podręcznik do klasy pierwszej, s. 133.

53 Ibidem.

54 Podręcznik do klasy szóstej, s. 130.

55 Podręcznik do klasy pierwszej, s. 133.

56 Podręcznik do klasy drugiej, s. 23.

57 Ibidem.

58 Podręcznik do klasy drugiej gimnazjum, s. 62.

59 Ibidem, s. 63.
} 
czym cały czas podkreślane jest, że kapłan powołany jest na służbę dla dobra wspólnoty Kościoła. Być może jest tak, dlatego że przez księży działa w Kościele katolickim sam Pan Jezus, o czym kilkakrotnie przypominają autorzy podręczników. Dowodem może być fragment: „Jezus Chrystus działa w Kościele poprzez wyświęcone osoby, które dzięki łasce Bożej działają tak, jak same z siebie nie byłyby w stanie działać”60. Księża powinni pracować z niezwykłą, bo pochodzącą z autorytetu Chrystusa, mądrością. Kapłan ma nie tylko przekazywać Boże objawienie i prawdy wiary, lecz także stać na ich straży. Z interpretacji podręczników wynika, że szczególną rolę przypisuje się biskupom, którzy przejęli rolę apostołów.

W podręcznikach występuje też ksiądz-dobry pasterz. Czasami zdarzają się sytuacje przełamujące dystans, jak odwiedzenie chorego chłopca przez księdza-wujka, rozmowa z dziewczynką na łące, przesłanie widokówki po koloniach uczniowi. Tego typu sytuacje wyrażają realną troskę o potrzeby wiernych, bycie blisko ich problemów, dla nich. Pochylają się nad chorymi w szpitalu. Co ciekawe, według autorów podręczników „biskupi, prezbiterzy i diakoni dysponują przemieniającą, uzdrawiającą i zbawczą mocą Chrystusa" ${ }^{1}$, co sprawia, że „nie działają mocą własną ani na podstawie swojej moralnej doskonałości, lecz in persona Christi [w osobie Chrystusa]. Reprezentują Chrystusa jako pasterza swego ludu i jako głowę Jego Ciała-Kościoła" ${ }^{2}$. Brzmi to bardzo mistycznie, ale nie ma nic wspólnego z magią, tylko z misją Kościoła, powołaniem. Najwięcej miejsca sakramentowi kapłaństwa poświęcone jest w podręcznikach do liceum, gdzie uczeń staje przed wyborem swoje dorosłej drogi życiowej.

W podręcznikach są też księża-misjonarze, którzy podobnie jak zakonnice-misjonarki wyjeżdżają daleko, aby ewangelizować: „opiekują się także biednymi ludźmi, pomagają im zdobyć jedzenie, ubranie, a nawet budować domy. Razem z ludźmi tworzą Kościól, czyli rodzinę Jezusa" ${ }^{63}$. Działalność misyjna wynika z nauczania Jezusa, który nakazał apostołom iść i rozgłaszać Ewangelię, „misja ta przekracza wszelkie ograniczenia: przestrzeni, czasu, rasy, religii, pochodzenia społecznego, płci”" ${ }^{2}$. Misjonarze mają za zadanie głosić wyzwolenie, które spełnić się ma w Jezusie Chrystusie.

Warto dobitnie podkreślić, co zresztą robią sami autorzy podręczników, że kapłanem może zostać wyłącznie mężczyzna - „Duch Święty uzdalnia powołanych do tego mężczyzn do służby w imieniu Jezusa Chrystusa całej wspólnocie Kościoła"65. Kościół katolicki całkowicie odrzuca posługę kapłańską kobiet i co ciekawe, nie wspomina, że w innych kościołach chrześcijańskich posługa taka jest uznawana na równi z męską, choć na każdym etapie kształcenia występuje rozdział ekumeniczny, w którym opisane są różne religie i wyznania. Na temat kapłaństwa kobiet katolicy

60 Podręcznik do klasy trzeciej gimnazjum, s. 90.

61 Podręcznik do klasy drugiej gimnazjum, s. 63.

62 Ibidem.

63 Podręcznik do klasy pierwszej, s. 132.

64 Podręcznik do klasy trzeciej gimnazjum, s. 100.

65 Ibidem. 
jednak milczą. Ojciec Joachim Badenim mówi: „Kapłaństwo kobiet odpada zupełnie. [...] Kobieta nie może prowadzić Eucharystii. Nie może ona wypowiadać słów: »To jest ciało moje...«. Byłby to nonsens. Ciało Chrystusa to ciało męskie. Wypowiadanie takich słów przez kobietę byłoby bluźnierstwem”. Filozof dodaje: „propozycja kapłaństwa kobiet jest przede wszystkim działaniem przeciw temu, co zrobił Chrystus" ${ }^{\text {"66 }}$.

Warto zaznaczyć, że obraz kapłana w podręcznikach jest wyidealizowany. Jest to zgodne z założeniami pedagogiki. Podręcznik zawiera wzorce osobowe. Pełni funkcję wychowawczą, dlatego nie można w nim odnaleźć wizerunków księży alkoholików, pedofili ani gejów. Podręczniki nie reagują na współczesne problemy nękające stan duchowny.

\section{Role zawodowe dzieci}

Uczeń to pierwsza „poważna” rola w życiu dziecka. Grupa ról rodzinnych wynikała ze stosunku relacji i pokrewieństwa, natomiast grupa zawodowa wynika z obowiązków wykonywanych przez poszczególnych członków grupy. Role ucznia i uczennicy związane są z rolami syna i córki, pozostają także w stałym związku z rolami nauczycielki i nauczyciela.

W mojej analizie zauważyłam, że uczniowie mają gorsze oceny od uczennic. Częściej mają problemy z nauką i problemy z koncentracją. Dostają jedynki, tróje. W podręczniku do klasy pierwszej zamieszczona jest modlitwa za „kolegę, który źle się uczy" ${ }^{67}$. Są typami urwisów. Na lekcjach zamiast słuchać nauczyciela lub nauczycielki myślą o dziewczynach. Ponadto ściągają na sprawdzianach. Odgrywają także rolę klasowych wesołków. Oznacza to, że od chłopców wymagana jest mniejsza dyscyplina, na więcej się im pozwala. Nie są ambitni, mają problemy z systematycznością i motywacją. Rozpiera ich energia. Mają problem z funkcjonowaniem w obrębie systemu szkolnego. Jednakże istnieje też pozytywny obraz ucznia. Chłopcy proszeni są o pomoc dziewczynkom w odrabianiu lekcji i nadrabianiu zaległości, w szczególności z matematyki. Pomagają także chorym kolegom, którzy mają zaległości: „Staś nie był w szkole, Andrzej pomaga mu z zaległościami”68.

Uczennice przedstawione $\mathrm{w}$ analizowanych podręcznikach są pilniejsze $\mathrm{w}$ nauce od chłopców i bardziej koleżeńskie: „Ewelina, która wszystko wiedziała i pocieszała, tych, których spotkała przykrość" ${ }^{69}$, „Ania najlepiej czyta”70. Uczennice dążą do wprowadzania harmonii. Uspakajają niegrzecznych chłopców na lekcji. Starają się

\footnotetext{
66 J. Badenim, Kobieta boska tajemnica, Kraków 2008, s. 99.

67 Podręcznik do klasy drugiej gimnazjum, s. 42.

68 Podręcznik do klasy pierwszej gimnazjum, s. 91.

69 Ibidem, s. 84.

70 Podręcznik do klasy drugiej, s. 48.
} 
łagodzić konflikty między dziećmi. Od najmłodszych lat mają w sobie pierwiastki kobiecości wynikające z daru Bożego. Często to dziewczynki znają prawidłowe odpowiedzi na pytania nauczycieli, jednak są one potwierdzane przez autorytet ucznia-chłopca. Ma to swoje źródło w stereotypowym postrzeganiu płci, w którym mężczyzna występuje w roli autorytetu, specjalisty.

$\mathrm{W}$ podręcznikach zbadałam także rolę ministranta. Co ciekawe, w podręcznikach ministrantami są wyłącznie chłopcy, mimo że kościół dopuszcza już posługę dziewcząt. Ministranci portretowani są na ilustracjach oraz zdjęciach. Służą do mszy, niosą krzyż, mają bardzo bliski kontakt z sacrum. Podczas mszy pomagają księdzu, a także czytają Pismo Święta na mszy. Są bardziej wtajemniczeni w kwestie wiary od dziewczynek. Monopłciowy obraz ministranta w podręcznikach wynika z trudności z przełamaniem mentalnych barier, teologii pastoralnej.

\section{Role zawodowe. Podsumowanie}

Przeanalizowane role płciowe wynikające z pełnionych obowiązków postanowiłam przedstawić w tabeli, sprawdzając, w ilu i w których podręcznikach się pojawiają. Pod tabelą umieściłam przygotowane przeze mnie zestawienie liczbowe i procentowe, $w$ ilu podręcznikach analizowane role wystąpiły.

Tabela 1. Zestawienie ról zawodowych we wszystkich podręcznikach

\begin{tabular}{|l|c|c|c|c|c|c|c|c|c|c|c|}
\hline & I & II & III & IV & V & VI & I & II & III & I & II \\
\hline nauczycielka & + & + & + & - & + & + & + & + & + & - & - \\
\hline nauczyciel & - & - & - & + & - & - & + & + & - & - & - \\
\hline lekarka & + & - & - & - & - & - & - & + & - & - & - \\
\hline lekarz & + & + & - & - & - & - & + & - & + & - & + \\
\hline uczeń & + & + & + & + & + & + & + & + & + & - & - \\
\hline uczennica & + & + & + & + & + & - & + & + & + & - & - \\
\hline zakonnica & + & - & - & - & - & + & - & + & + & + & + \\
\hline ksiądz & + & + & + & + & + & + & + & + & + & + & + \\
\hline ministrant & + & + & - & - & - & + & - & + & - & + & - \\
\hline
\end{tabular}

Źródło: badania własne.

Tabela 2. Procentowe porównanie płciowych ról zawodowych we wszystkich podręcznikach

\begin{tabular}{|l|l|l|}
\hline Nauczycielka $8(72 \%)$ & Lekarz 5 (45\%) & Zakonnica 6 (54\%) \\
\hline Nauczyciel $3(27 \%)$ & Uczeń $9(81 \%)$ & Ksiądz 11 (100\%) \\
\hline Lekarka 2 (18\%) & Uczennica 8 (72\%) & Ministrant 5 (45\%) \\
\hline
\end{tabular}

Źródło: badania własne. 
Najczęściej występującą rolą płciową zawodową wśród wszystkich ról, mężczyzn i kobiet, okazał się ksiądz, wśród kobiet - nauczycielka. Co ciekawe, uczniowie pojawiali się o $10 \%$ częściej niż uczennice. Zaskoczeniem nie są najniższe wyniki: nauczyciel, który pojawił się tylko w trzech podręcznikach, oraz lekarka tylko w dwóch, ponieważ zgodnie z tradycyjnym stereotypem płciowym lekarzami są mężczyźni, kobiet częściej są pielęgniarkami lub pomocnicami lekarza (należy zaznaczyć, że ta rola wystąpiła tylko we wzmiance!), natomiast nauczycielkami częściej są kobiety, ponieważ jest to rola opiekuńczo-wychowawcza, tradycyjnie przypisywana kobietom.

Oprócz opisanych ról płciowych wynikających z pełnionych obowiązków występuje wiele ról pobocznych. Często nie odgrywają one żadnej ważnej roli, są wspominane przez autorów podręcznika albo występują tylko na ilustracjach.

Tabela 3. Kobiety i mężczyźni w rolach zawodowych

\begin{tabular}{|c|c|}
\hline Płeć żeńska & Płeć męska \\
\hline Nauczycielka & Nauczyciel \\
\hline & Kapłan \\
\hline Zakonnica & Zakonnik \\
\hline Lekarka & Lekarz \\
\hline & Taksówkarz \\
\hline Pielęgniarka & \\
\hline Sprzedawczyni & \\
\hline & Biznesmen \\
\hline & Inżynier \\
\hline Uczennica & Uczeń \\
\hline
\end{tabular}

Źródło: badania własne.

\section{Wnioski}

Elżbieta Górnikowska-Zwolak oraz Katarzyna Rajca podkreślają, że „kościelne spojrzenie na kobietę jest spojrzeniem przez pryzmat rodziny i macierzyństwa"71. Kościół jawi się tutaj więc jako instytucja konstytuująca patriarchat, dlatego że „sprowadza kobiety do roli żon i matek"72.

Elizabeth Cady Santon w Woman's Bible wypowiada się jeszcze bardziej krytycznie na temat stosunku kościoła do płci i statusu kobiet i mężczyzn. Autorka pisze:

71 E. Górnikowska-Zwolak, K. Rajca, op. cit., s. 12.

72 Ibidem, s. 17. 
„wierzenia, przepisy, pisma religijne” bazują na patriarchalnej idei, mówiącej, że „kobieta została stworzona po mężczyźnie, z mężczyzny i dla mężczyzny, jako istota pośledniejsza i podporządkowana mężczyźnie"73.

W pismach Kościoła niejednokrotnie podkreślana jest naturalna różnica między płciami. Różnica ta jest częścią Bożego dzieła stworzenia, zamysłu. To, że kobiety i mężczyźni są różni, jest naturalne, a nie wynikające z kultury. W tym ujęciu to biologia warunkuje to, co oznacza męskość, a co kobiecość.

W artykule przeanalizowałam jedenaście podręczników do religii wydawnictwa WAM, stanowiły one swoistą całość, od pierwszej klasy szkoły podstawowej do trzeciej liceum. Moje badania dowiodły, że w podręcznikach utrwalony zostaje tradycyjny podział ról płciowych. Podręczniki reprodukują stereotypy płciowe. $\mathrm{W}$ toku kolejnych lat nauki, poszczególne role są powielane. Jeżeli chodzi o role wynikające z pełnionej funkcji, zawody kobiety częściej osadzane są w rolach opiekuńczo-wychowawczych. W ich pracy ważne są relacje $z$ innymi i służba drugiemu człowiekowi. Zarówno męskie, jak i żeńskie postawy wynikające z pełnienia „zawodu misyjnego" są w podręcznikach gloryfikowane, jednak ich reprezentacja różni się. Kobieta nauczycielka to pozytywistyczna siłaczka, nauczyciel to autorytet. Lekarka zawsze jest gotowa do udzielenia pomocy, lekarz to specjalista, np. uznany chirurg. W ani jednym podręczniku nie pojawia się kobieta pracująca daleko od domu, matka nieobecna. Od kobiet wymagana jest zdolność łączenia prac domowych z aktywnością zawodową. Mężczyźni często są nieobecni. Wyjeżdżają w długie podróże służbowe. Praca kobiet traktowana jest jako dodatek do pracy mężczyzny. To on ma za zadanie utrzymać rodzinę. Kobieta może realizować się zawodowo, ale nie może odbić się to negatywnie na jej wkładzie w opiekę nad domem i rodziną — dziećmi i mężem. Ten wzór postępowania wynika bezpośrednio z założeń „prawdziwego feminizmu” Jana Pawła II. Papież niejednokrotnie podkreślał, że kobieta i mężczyzna są równi sobie w godności osobowej, bo dostali ją od Boga. Różnią się jednak ich powołania - mają do spełnienia inne misje. Bóg przygotował dla nich inne role życiowe. W nauce społecznej Kościoła powtarza się postulat o dowartościowanie pracy domowej kobiet, które decydują się na rezygnację z aktywności zawodowej na rzecz rodziny. Jednocześnie zauważane jest, że obecna sytuacja na rynku pracy zmusza oboje rodziców do wykonywania pracy zarobkowej. Postulowane są więc zmiany. Płaca mężczyzny powinna być wystarczająca na utrzymanie rodziny. Prawa kobiet do wolnego wyboru pracy nie są zabrane, jednak najważniejsze jest to, aby umiały one pogodzić pracę zawodową ze swoim naturalnym, boskim powołaniem.

Dużo miejsca w podręcznikach autorzy poświęcają przedstawieniu ról osób konsekrowanych. Są to zakonnice, księża oraz misjonarze i misjonarki. Podobnie jak w przypadku osób świeckich, kobiety pełnią tu role opiekuńczo-wychowawcze. Za-

73 E.C. Santon, The Woman's Bible, t. 1, New York 1972, s. 7. Za: R. Pytnam Tong, Myśl feministyczna. Wprowadzenie, przeł. J. Mikos, B. Umińska, Warszawa 2002, s. 65. 
konnice często ukazywane są w kontekście opieki nad dziećmi. Są przedszkolankami, nauczycielkami religii. Zajmują się dziećmi w kościele, np. przez prowadzenie chóru. Na misjach też uczą dzieci. Pracują także w misyjnych szpitalach. Pielęgnują chorych. Księża pokazani są jako eksperci od życia duchowego. Autorzy podręczników często podkreślają, że praca kapłanów jest Bożym powołaniem na służbę dla drugiego. Jednak wizerunek księży zawarty w podręcznikach jest analogiczny do świeckich mężczyzn. Pokazani są oni jako eksperci, mają władzę, wcale nie dekoduje się ich jako skromne sługi Boże, troskliwych pasterzy. Są oni pokazani jako wybrańcy obdarzeni dodatkowymi, boskimi mocami, dzięki którym mogą udzielać sakramentów. Pełnią funkcje rytualne i magiczne. Dzięki nim grzechy są odpuszczane, oni dopuszczają zakochanych do bycia małżeństwem. Oczywiście autorzy podręcznika piszą, że są oni łącznikiem, przez który sam Bóg udziela sakramentów, jednak gdyby nie oni, sakramenty nie byłyby udzielone. Daje to księżom władzę.

Wizerunki ról płciowych wynikających z pełnionego zawodu są silnie idealizowane. Uczeń nie znajdzie tu przykładów lekarzy-łapowników, policjantów torturujących i uciekających się do przemocy. Nie ma tu także nauczycieli mających romans z uczniami ani księży pedofili. Co więcej, obraz świata przedstawiony w badanych przeze mnie podręcznikach jest heteronormatywny. Homoseksualizm to grzech i zepsucie, zagraża polskim rodzinom i tradycyjnym wartościom.

Podsumowując, feminizm katolicki zakłada równowartość istnienia kobiety i mężczyzny jako stworzeń Bożych. Jednocześnie podkreślany jest tradycyjny podział ról płciowych, sankcjonowany jako naturalny, pochodzący z Bożego zamysłu. Kobieta i mężczyzna są sobie równi, ale różni i powołani do innych celów. Kościół katolicki odrzuca zdecydowanie podział na płeć biologiczną i kulturową. Gender przedstawiana jest przez ludzi Kościoła nie jako nauka, a jako szkodliwa ideologia zagrażająca polskim rodzinom i promująca homoseksualizm (co jednoznacznie wynika z listu z okazji Święta rodziny).

\section{Professional roles in Polish Catholic religion textbooks from the perspective of gender criticism as exemplified by textbooks published by WAM}

\section{Summary}

In the article the author examines eleven textbooks used in the teaching of the Catholic religion, from year one of primary school to year three of high school. She focuses on a gender analysis of professional roles presented in the textbooks in question. The professional roles presented in them are those of adults (like teacher, doctor, priest, nun) and children (pupil, altar boy). Gender criticism is juxtaposed with the premises of Christian feminism as well as the Catholic Church's personalist concept of upbringing. 